\title{
Self-sterility in the hexaploid Handroanthus serratifolius (Bignoniaceae), the national flower of Brazil
}

\author{
Mariana Ferreira Alves ${ }^{1}$, Mariana Oliveira Duarte ${ }^{1}$, Paulo Eugênio Oliveira ${ }^{1}$ and Diana Salles Sampaio ${ }^{1,2}$
}

Received: 3 May, 2013. Accepted: 16 July, 2013

\begin{abstract}
Polyploidization is common among angiosperms and might induce typically allogamous plants to become autogamous (self-compatible, relying on sexual self-fertilization) or apomictic (achieving asexual reproduction through seeds). This work aimed to determine whether neopolyploidy leads to the breakdown of the self-incompatibility system in the hexaploid non-apomictic species Handroanthus serratifolius (Vahl) S. Grose, through analyses of its floral biology, pollination biology and breeding system. Although anthesis lasted for three days, increasing the overall floral display, receptivity decreased as of the second day. Centridini and Euglossini bees were the main pollinators, and low nectar availability $(1.95 \pm 1.91 \mu \mathrm{l} /$ flower $)$ might have obliged them to visit multiple flowers. We observed low reproductive efficacy. That might be explained by self-sterility and by the great number of flowers per individual, which could increase the frequency of geitonogamy. Ovule penetration by the pollen tubes in self-pollinated pistils with posterior abscission indicated late-acting self-incompatibility in $\mathrm{H}$. serratifolius, as observed in other diploid Bignoniaceae species, although inbreeding depression cannot be excluded. The self-sterility found in the monoembryonic, hexaploid individuals studied here contrasts with the results for other neopolyploid Handroanthus and Anemopaegma species, which are often autogamous and apomictic. Our results suggest that neopolyploidy is not the main factor leading to self-fertility in Handroanthus.
\end{abstract}

Key words: apomixis, late-acting self-incompatibility, monoembryony, polyploidy, Tabebuia serratifolia

\section{Introduction}

Among the 827 species of Bignoniaceae (Olmstead et al. 2009), the breeding system has been determined for only 62. Eighty percent of the studied species present self-sterility, which is often characterized as a result of late-acting self-incompatibility (LSI) mechanisms (Gibbs \& Bianchi 1993; Bittencourt et al. 2003; 2011; Bittencourt \& Semir 2005; Gandolphi \& Bittencourt 2010). To date, all neopolyploid Bignoniaceae species have been found to be self-compatible (Gobatto-Rodrigues \& Stort 1992; Bittencourt \& Semir 2005; Bittencourt \& Moraes 2010; Firetti-Leggieri et al. 2013; Sampaio et al. 2013a), although not all self-compatible species are neopolyploids (Dutra \& Machado 2001; Yanagizawa \& Maimoni-Rodella 2007; Qu et al. 2007). Therefore, self-fertility in Bignoniaceae could be caused by various factors, of which polyploidy appears to be one of the most important.

Polyploidy is whole-genome duplication, often caused by meiotic abnormalities (Ramsey \& Schemske 1998). The most common chromosome number in somatic cells of Bignoniaceae is $2 \mathrm{n}=2 \mathrm{x}=40$, which is considered the diploid number of the family (Goldblatt \& Gentry 1979).
Neopolyploid species (i.e., polyploids whose closely related diploid species are not extinct) have been found in the genera Anemopaegma (Firetti-Leggieri et al. 2011, Sampaio et al. 2013b), Dolichandra (Piazzano 1998), Handroanthus (Piazzano 1998; Sampaio 2010) and Pyrostegia (Goldblatt \& Gentry 1979; Sampaio 2010), with chromosome numbers in somatic cells of $2 n=60,2 n=80$ and $2 n=120$, respectively. Studies of the breeding systems of the neopolyploid species of Anemopaegma and Handroanthus have shown self-fertility and polyembryony (Bittencourt \& Semir 2005; Bittencourt \& Moraes 2010; Mendes-Rodrigues et al. 2012; Firetti-Leggieri et al. 2013; Sampaio et al. 2013a). Histological analyses have shown that the supernumerary embryos found in polyembryonic seeds arise from somatic tissues of the ovule in Handroanthus ochraceus (Cham.) Mattos (Costa et al. 2004), H. chrysotrichus (Mart. ex DC) Mattos (Bittencourt \& Moraes 2010) and Anemopaegma acutifolium DC. (Sampaio et al. 2013b), indicating the occurrence of sporophytic apomixis. On the basis of those findings, high frequencies of polyembryonic seeds have been used as evidence of sporophytic apomixis in Bignoniaceae (Mendes-Rodrigues et al. 2012, Firetti-Leggieri et al. 2013; Sampaio et al. 2013b).

\footnotetext{
${ }^{1}$ Instituto de Biologia, Universidade Federal de Uberlândia, Campus Umuarama, Uberlândia, Minas Gerais, Brazil

${ }^{2}$ Author for correspondence: sampaiodsbot@yahoo.com.br
} 
Although neopolyploidy seems to be effectively associated with the breakdown of self-incompatibility systems, especially the gametophytic system (de Nettancourt 1977; Richards 1986; Levin 2002; Pannell et al. 2004; Barringer 2007), some studies suggest that the self-fertility found in these pseudogamic apomictic sporophytic species is not determined exclusively by neopolyploidy (Oliveira $e t$ al. 1992; Bittencourt \& Semir 2005; Bittencourt \& Moraes 2010; Sampaio et al. 2013a). The LSI found in most species of Bignoniaceae allows pollen tube growth, ovule penetration, fertilization and endosperm development prior to self-pollinated pistil abscission (Bittencourt et al. 2003; 2011; Bittencourt \& Semir 2005; Gandolphi \& Bittencourt 2010). In apomictic species, adventitious embryos develop irrespective of pollination but are able to reach maturity only when the endosperm is available (Bittencourt \& Moraes 2010; Sampaio et al. 2013b). Therefore, the presence of adventitious embryos in self-fertilized ovules with endosperm development, which is common in LSI species, could trigger the fruit-set of self-pollinated pistils (Oliveira et al. 1992; Bittencourt \& Moraes 2010; Sampaio et al. 2013a).

Handroanthus serratifolius (Vahl) S. Grose, known in Brazil as yellow ipê, is a tree that is widely distributed in Latin America. Its massive presentation of yellow flowers makes it a highly conspicuous element of the landscape. Due to its ubiquity and beauty, the species was designated the national flower of Brazil and is the emblem of the Brazilian Botanical Society (Gentry 1992b). In addition to its ornamental value (Lorenzi 1992), the species is important for the timber industry, as well as for the pharmaceutical industry, which uses it for a variety of purposes (Gentry 1992a, Lorenzi 1992), including cancer-related research (Oliveira et al. 2002; Salustiano et al. 2010). This species is reportedly hexaploid, with $2 \mathrm{n}=120$ chromosomes, presenting monoembryonic populations (Sampaio 2010) and populations with high percentages of polyembryonic seeds (Mendes-Rodrigues et al. 2012). This makes H. serratifolius an excellent model for the study of the effects that neopolyploidy and apomixis have on the LSI system of Bignoniaceae. Given that monoembryonic seeds indicate sexual and non-apomictic reproduction, we tested the hypothesis that neopolyploidy, irrespective of sporophytic apomixis (adventitious embryos), leads to self-fertility in a species belonging to a primarily allogamous family.

\section{Material and methods}

\section{Studied species and sites}

Handroanthus serratifolius can reach a height of $30 \mathrm{~m}$ and is found in areas of forest or savanna (Gentry 1992b). Although the species shows great morphological diversity, it is typically characterized by compound leaves with three to seven leaflets (commonly five), entire to serrated (commonly serrated), often glabrous and inconspicuously lepidote. The calyx is campanulate, sparsely pubescent, with three to five lobes, and the tubular corolla is yellow (Fig. 1A-C). The fruit is a straight capsule, almost glabrous, inconspicuously lepidote with longitudinal grooves and many extrafloral nectaries that resemble warty lumps (Fig. 1D-G). Handroanthus serratifolius is a deciduous plant and, during the dry season, presents massive flowering, which lasts for approximately 45 days, fitting the "big bang" phenology, sensu Gentry (1974). The field work, carried out from July to September of 2011, involved three individuals located in Uberaba $\left(19^{\circ} 39^{\prime} 51.27^{\prime \prime} \mathrm{S} ; 47^{\circ} 58^{\prime} 05.40^{\prime \prime} \mathrm{W}\right)$ and three located in Uberlândia (18 $53^{\prime} 02.08^{\prime \prime S}$; $48^{\circ} 15^{\prime} 33.05^{\prime \prime} \mathrm{W}$ and $18^{\circ} 53^{\prime} 18.76^{\prime \prime}$; $48^{\circ} 15^{\prime} 36.70^{\prime \prime} \mathrm{W}$ ), both of which are cities in the state of Minas Gerais, Brazil. The Uberaba individuals had been cultivated on the campus of the Triangulo Mineiro Federal Institute for Education, Science and Technology. Although we identified eight individuals at the Uberaba site, only three flowered during the study period. Of the three Uberlândia individuals, two had been cultivated on the Umuarama Campus of the Federal University of Uberlândia, where we also identified three other H. serratifolius individuals that did not flower during the study. The third Uberlândia individual had been cultivated at the Julieta Diniz Municipal Center for Educational Projects and Studies, where it was the only such individual identified. The two Uberlândia sites are within $600 \mathrm{~m}$ of each other, which probably allows pollen to flow between them. To access the treetops, we had the assistance of trucks from the Minas Gerais Electric Company equipped with cherry pickers used for wiring repair (Fig. 1H, I). We also used a 3-m aluminum ladder (Fig. 1J). Voucher specimens were deposited at the Herbarium of the Federal University of Uberlândia (code, HUFU; Uberaba collection: HUFU 60075; Uberlândia collections: HUFU 48932, 52591).

\section{Embryo number and chromosome number}

Most of the studied trees have been already analyzed for the number of embryos per seed in a previous study, and all seeds evaluated were classified as monoembryonic (Sampaio 2010). If the studied plants were sporophytic apomicts, high proportions of polyembryonic seeds (>20\%) were expected. However, a low proportion of polyembryonic seeds $(<5 \%)$ can be attributed to some exceptions in the sexual process or to other types of apomixis (Mendes-Rodrigues et al. 2012, Firetti-Leggieri et al. 2013; Sampaio et al. 2013b). One investigation of the proportion of polyembryonic seeds in a population of Handroanthus serratifolius showed little variation among individuals (Mendes-Rodrigues et al. 2012). Apparently, when a plant is polyembryonic, all fruits present polyembryonic seeds. In order to confirm the number of embryos per seed for all individuals (through the number of emerged seedlings), seeds from at least two fruits from each plant were sown in general-purpose polystyrene boxes (Gerbox; J.Prolab Ind. e Comércio de Produtos para Laboratório Ltda., São José dos Pinhais, Brazil), on cotton and 

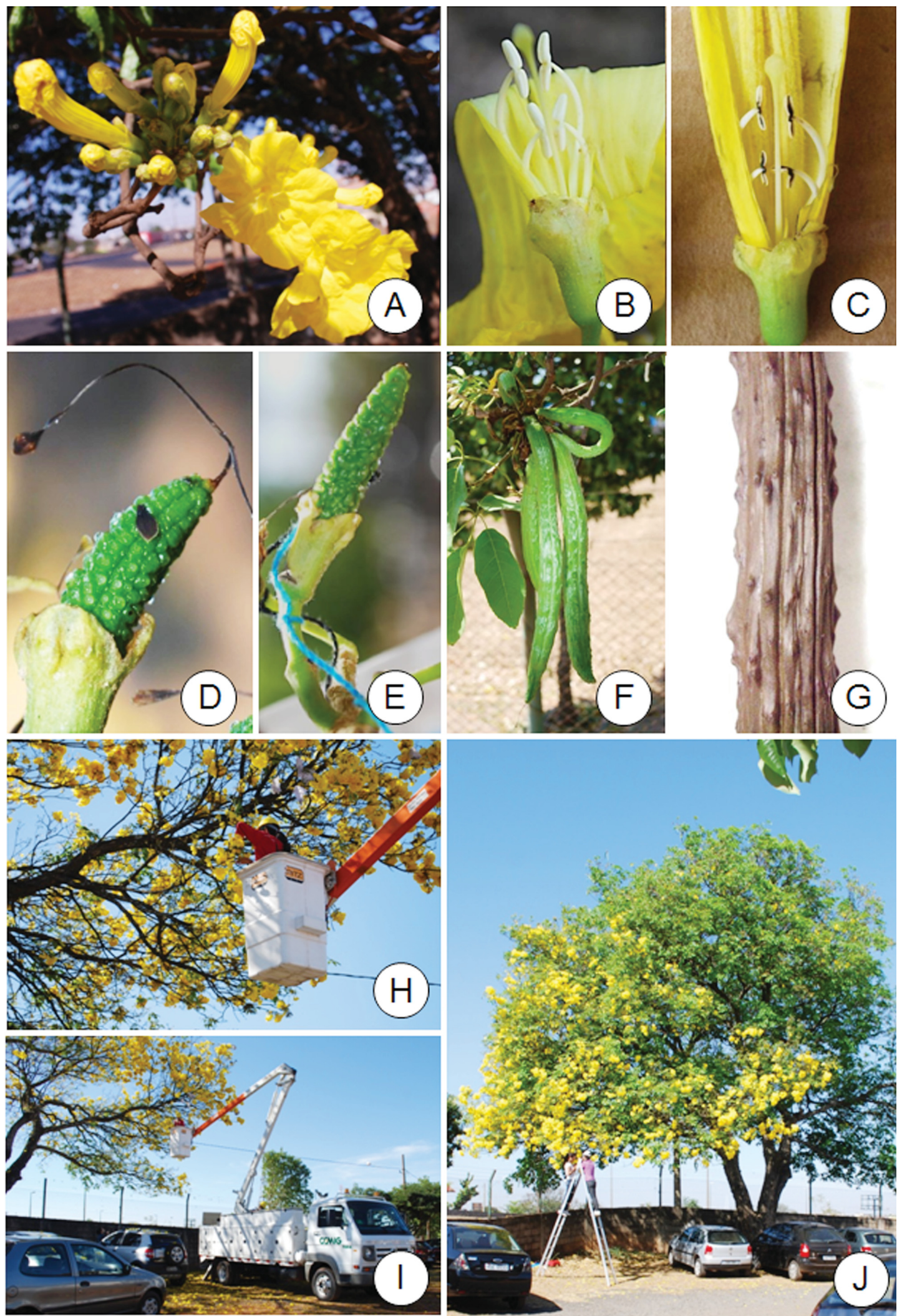

Figure 1. Flowers, fruits and tree of Handroanthus serratifolius (Vahl) S. Grose, in the city of Uberlândia, in the state of Minas Gerais, Brazil. A. Pre-anthesis buds and flowers during anthesis. B. Corolla tube open, exposing the white anthers of pre-anthesis buds. C. Corolla tube open, exposing the blackened anthers of flowers after the first day of anthesis. D. Young fruit with active nectaries. E. Young-fruit from hand self-pollinated pistil. F. Developed, almost mature fruits. G. Mature fruits with longitudinal grooves and many extrafloral nectaries that resemble warty lumps. H, I. Access to the treetop with the assistance of a truck from the Minas Gerais Electric Company equipped with a cherry picker (Fig. 1H, I). J. Access to the treetop with a 3-m aluminum ladder. 
filter paper moistened with distilled water. The boxes were maintained at room temperature $\left(\approx 28^{\circ} \mathrm{C}\right)$ and under natural light. We sowed 50 seeds from the Uberaba individuals and 150 seeds from the Uberlândia individuals. Of those 200 seeds, 95 germinated (33 from Uberaba and 62 from Uberlândia), and the seedlings were counted.

Although the chromosome number of Handroanthus serratifolius has been already determined, variations in this parameter have been observed among populations in other Handroanthus species (Sampaio 2010). Seeds from all individuals were sown as described above, in order to obtain the root apical meristems for the analysis of cells in the mitotic metaphase. The root tips were pretreated in a saturated solution of paradichlorobenzene (Sigma-Aldrich, St. Louis, MO, USA) for $4 \mathrm{~h}$ at $16-18^{\circ} \mathrm{C}$. They were then fixed in Carnoy's fixative (3 parts analytical grade ethanol and 1 part glacial acetic acid) for $24 \mathrm{~h}$ and stored at $<0^{\circ} \mathrm{C}$ in $70 \%$ ethanol. The root tips were digested in $5 \mathrm{~N} \mathrm{HCl}$ for $20 \mathrm{~min}$, coverslipped and subjected to the usual squashing technique. Coverslips were removed after immersion in liquid nitrogen. Slides were stained with Giemsa 2\% (Guerra 1983) and mounted with Entellan (Merck, Whitehouse Station, NJ, USA). We analyzed slides of three seedlings from Uberaba, one from each individual, and eight from Uberlândia, four seedlings from one individual and two seedlings from each of the other two. We counted 10 cells with good chromosome morphology and spreading on the slides of the Uberaba population and 39 on the slides of the Uberlândia population. The chromosome counts were performed under light microscopy with an optical microscope (BX51; Olympus, Tokyo, Japan), and good metaphase plates were photographed with a digital camera (DP70; Olympus).

\section{Floral biology and floral visitors}

Twenty-nine floral buds from four individuals (three from Uberaba and one from Uberlândia) were marked and bagged with nylon mesh bags to exclude floral visitors. Floral biology was observed at the onset of anthesis and at 8, 24, 48 and $72 \mathrm{~h}$ thereafter, until the corolla wilted or dropped. We analyzed floral longevity, stigmatic receptivity (evaluated by the analysis of stigma opening and sensitivity), pollen presentation and scent production.

To analyze nectar features, 50 buds in pre-anthesis from four individuals (three from Uberaba and one from Uberlândia) were bagged. Measurements were taken in the early morning and late afternoon until the end of anthesis, in a total of seven time points, measuring different flowers per time point. To estimate the amount of accumulated nectar, $10-\mu \mathrm{l}$ microcapillaries were used. To estimate nectar concentration, a handheld refractometer with a $1 \%$ scale (Eclipse; Bellingham \& Stanley Tunbridge Wells, UK) was used for the measurement of soluble sugars (Kearns \& Inouye 1993).

Pollen viability was estimated by staining pollen grains with acetocarmine. For this analysis, 16 pre-anthesis floral buds from five individuals (two from Uberaba and three from Uberlândia) were collected and stored in $70 \%$ ethanol. For each flower, two slides were mounted, each with pollen grains of one anther, to which were added a drop of acetocarmine and a drop of 50\% glycerol in water (Dafni et al. 2005). The analysis was performed under light microscopy, and 300 pollen grains were analyzed per slide. Slides with few or no stained pollen grains, which indicates the absence of cytoplasm, were classified as non-viable samples. To estimate the number of pollen grains per flower, 14 pre-anthesis buds from three individuals (from Uberlândia only) were stored in $70 \%$ ethanol. We estimated the number of pollen grains in a dilution derived from the compounds of two anthers from the same flower, separately, in $1 \mathrm{ml}$ of $50 \%$ glycerol in water. For each anther, eight counts were made in a Neubauer chamber (Dafni et al. 2005) under light microscopy. The number of ovules per ovary was counted in 15 flowers collected from three individuals (from Uberlândia only) and stored in $70 \%$ ethanol. For the counting, the ovaries were dissected under a stereomicroscope (SZX12; Olympus).

The short flowering period and height of the Handroanthus serratifolius individuals impeded the observation of floral visitors and precluded their collection. Floral visitors were observed for approximately $6 \mathrm{~h}$, during the morning or the afternoon, in two individuals within each population. The floral visitors were identified visually during the visits and were classified as "effective pollinators" when they came into contact with the stigma and stamens; as "nectar robbers" when they obtained nectar without entering the corolla tube; and as "pollen robbers" when they entered the corolla tube but due to their behavior and small size, rarely came into contact with the stigma.

\section{Breeding system}

In two individuals from Uberaba and three from Uberlândia, floral buds were isolated with nylon mesh bags to exclude floral visitors. In one individual from Uberaba, the breeding system could not be tested, because it showed very few flowers in the top of the tree when the experiments were conducted. First-day flowers to be hand self- or cross-pollinated were emasculated immediately before pollination, in order to avoid spontaneous self-pollination. In self-pollinations, we used the pollen grains of the same flower, whereas in cross-pollinations, we used pollen from individuals at least $10 \mathrm{~m}$ away at the same site. Some bagged buds were marked to check for spontaneous self-pollination and others were emasculated before isolation to confirm the absence of apomixis with autonomous endosperm formation. The natural fruit set was estimated by monitoring marked, nonbagged flowers. The index of self-incompatibility (ISI) was determined by calculating the ratio of hand self-pollination to cross-pollination fruit-set (Bullock 1985). As ISI $<0.25$ classifies a species as self-incompatible (sensu Bawa 1974). The natural/hand cross-pollination fruit-set ratio was also 
used as an estimate of reproductive efficacy (Ruiz \& Arroyo 1978). Fruits derived from experimental and natural pollinations were collected, and their lengths were measured. The number of seeds per fruit was also evaluated.

For three Uberaba individuals and one Uberlândia individual, we collected pistils from additional hand selfand cross-pollinations at post-pollination hours $12(\mathrm{n}=9$ and $n=7$, respectively), 24 ( $n=8$ and $n=9$, respectively) and 48 ( $\mathrm{n}=5$ and $\mathrm{n}=7$, respectively). The pistils were stored in $70 \%$ ethanol for subsequent analysis of in situ pollen tube growth. The ovary wall was removed to expose the ovules. Pistils were softened in $9 \mathrm{M} \mathrm{NaOH}$ solution at $55^{\circ} \mathrm{C}$ for 15 min, washed in running water, and stained with a solution of aniline blue and water (adapted from Martin 1959). The pistils were analyzed with an epifluorescence microscope (Axioskop; Carl Zeiss, Jena, Germany).

Measures of ovary length and width (collected in three individuals from Uberaba and one from Uberlândia) in hand self- and cross-pollinated pistils collected at postpollination hours $24(n=5$ and $n=4$, respectively), $48(n=4$ and $n=5$, respectively), $72(n=2$ and $n=3$, respectively) and 120 hours ( $\mathrm{n}=2$ and $\mathrm{n}=5$, respectively) were carried out with a digital caliper $(300 \mathrm{~mm} / 12$ in., in 0.01 -in. increments; Digimess Instrumentos de Precisão Ltda., São Paulo, Brazil). All pistils were fixed in a $1 \%$ glutaraldehyde and $4 \%$ formaldehyde solution (McDowell \& Trump, 1976) in 0.1 $\mathrm{M}$ sodium phosphate buffer, $\mathrm{pH}$ 7.2, before measurements.

\section{Statistical analysis}

In order to compare ovary length and width between treatments and time points, we employed the Mann-Whitney and Kruskal-Wallis tests, using the statistical package Statistica 7 for Windows (StatSoft 2004).

\section{Results}

\section{Embryo number and chromosome number}

All seeds germinated were monoembryonic. Among the cells analyzed in the three seedlings derived from Uberaba individuals, six showed $2 \mathrm{n}=120$ chromosomes, and the other cells presented small variations (one with $2 \mathrm{n}=117$, two with $2 \mathrm{n}=116$ and one with $2 \mathrm{n}=114$ ). Among the four seedlings derived from two of the Uberlândia individuals, seven cells were found to have $2 \mathrm{n}=120$ chromosomes (Fig. 2), whereas two cells had $2 n=119$ and one had $2 n=116$. Among the cells analyzed in the four seedlings derived from the remaining Uberlândia individual, 20 had $2 \mathrm{n}=118$ chromosomes and nine had $2 \mathrm{n}=116$.

\section{Floral biology and floral visitors}

In Handroanthus serratifolius, the onset of anthesis was irregular in its timing, most often commencing in the morning (at 7:30 in 55\%; at 12:30 in 24\%; and at 17:00 in $21 \%$ ).
Anthesis lasted for two days (in 20.7\%) or three days (in $79.3 \%$ ). The end of anthesis was defined as the wilting and dropping of the corolla. On the first day of anthesis, all flowers presented a showy yellow corolla (Fig. 1A) and a sweet scent (Tab. 1). Pollen presentation and stigmatic receptivity were observed in most flowers at $8 \mathrm{~h}$ after the onset of anthesis (Tab. 1). At $24 \mathrm{~h}$ after the onset of anthesis, flowers began to lose their sweet scent and pollen began to run out from some flowers (pollen grains fell down onto the corolla tube), although stigmatic receptivity remained constant (Tab. 1). By approximately $48 \mathrm{~h}$ after the onset of anthesis, the flowers had lost most of their scent and pollen (Tab. 1), the anthers had blackened (Fig. 1B, C) and the stigmatic receptivity had decreased by approximately $60 \%$ (Tab. 1). At $72 \mathrm{~h}$ after the onset of anthesis, flowers were wilting and falling, with no scent and no pollen, although a few flowers (17\%) still showed some stigmatic sensitivity (Tab. 1).

Among the 50 flowers analyzed for nectar features, 19 (38\%) presented no nectar during anthesis. During anthesis, the mean accumulated volume of nectar was 1.95 $\pm 1.91 \mu \mathrm{l}$ and the mean nectar concentration was $34.63 \pm$ $4.9 \%$ (Tab. 2). Although nectar volume seemed to increase on the second day of anthesis, statistical analyses were not performed due to the small number of flowers with nectar available at some time points (Tab. 2). It was not possible to

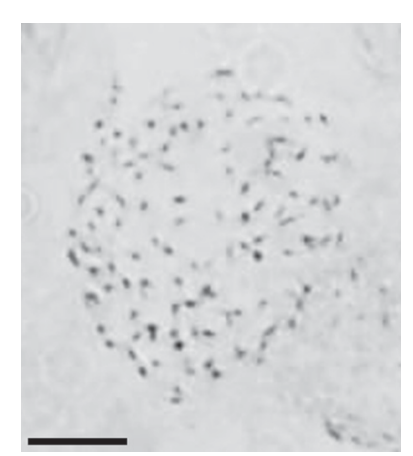

Figure 2. Cell from the root apical meristem of Handroanthus serratifolius (Vahl) S. Grose, Uberlândia, MG, Brazil, in mitotic metaphase, showing $2 \mathrm{n}=6 \mathrm{x}=120$ chromosomes. Scale $=10 \mu \mathrm{m}$.

Table 1. Proportional distribution of flowers with distinct features at five time points during anthesis in Handroanthus serratifolius (Vahl) S. Grose, in the cities of Uberaba and Uberlândia, state of Minas Gerais, Brazil.

\begin{tabular}{|c|c|c|c|c|c|}
\hline \multirow{3}{*}{ Feature } & \multirow{3}{*}{$\begin{array}{c}\text { Anthesis } \\
\text { onset } \\
(\mathrm{n}=29) \\
\mathrm{n}(\%)\end{array}$} & \multicolumn{4}{|c|}{ Time after anthesis onset } \\
\hline & & $\begin{array}{c}8 \mathrm{~h} \\
(\mathrm{n}=27)\end{array}$ & $\begin{array}{c}24 \mathrm{~h} \\
(\mathrm{n}=26)\end{array}$ & $\begin{array}{c}48 \mathrm{~h} \\
(\mathrm{n}=22)\end{array}$ & $\begin{array}{c}72 \mathrm{~h} \\
(\mathrm{n}=6)\end{array}$ \\
\hline & & $\mathrm{n}(\%)$ & $\mathrm{n}(\%)$ & $\mathrm{n}(\%)$ & $\mathrm{n}(\%)$ \\
\hline $\begin{array}{l}\text { Strong (sweet) } \\
\text { scent }\end{array}$ & $29(100)$ & $27(100)$ & $15(58)$ & $5(23)$ & $0(0)$ \\
\hline $\begin{array}{l}\text { Weak (sweet) } \\
\text { scent }\end{array}$ & $0(0)$ & $0(0)$ & $9(34)$ & $11(55)$ & $0(0)$ \\
\hline $\begin{array}{l}\text { Pollen } \\
\text { presentation }\end{array}$ & $14(50)$ & $22(85)$ & $16(62)$ & $7(32)$ & $0(0)$ \\
\hline $\begin{array}{l}\text { Stigma } \\
\text { receptivity }\end{array}$ & $11(38)$ & $23(85)$ & $23(88)$ & $7(32)$ & $1(17)$ \\
\hline
\end{tabular}


Table 2. Concentration of soluble sugars and nectar volume at seven time points during anthesis in Handroanthus serratifolius (Vahl) S. Grose, in the cities of Uberaba and Uberlândia, state of Minas Gerais, Brazil.

\begin{tabular}{|c|c|c|}
\hline \multirow{2}{*}{ Anthesis time point } & Concentration (\%) & Volume $(\mu \mathrm{l})$ \\
\hline & Mean \pm SD & Mean \pm SD \\
\hline \multicolumn{3}{|l|}{ Day 1} \\
\hline 9:30 & $30.25 \pm 3.12(\mathrm{n}=2)$ & $0.79 \pm 0.55(\mathrm{n}=2)$ \\
\hline $15: 30$ & $39.00 \pm 2.83(n=2)$ & $0.79 \pm 0.82(\mathrm{n}=5)$ \\
\hline \multicolumn{3}{|l|}{ Day 2} \\
\hline $7: 30$ & $35.08 \pm 4.75(n=6)$ & $3.13 \pm 2.46(n=6)$ \\
\hline $17: 00$ & $35.80 \pm 4.80(n=5)$ & $3.45 \pm 2.48(\mathrm{n}=6)$ \\
\hline \multicolumn{3}{|l|}{ Day 3} \\
\hline $8: 20$ & $30.90 \pm 2.75(n=5)$ & $1.18 \pm 0.56(n=5)$ \\
\hline $17: 00$ & $38.00 \pm 6.56(\mathrm{n}=3)$ & $1.56 \pm 1.28(\mathrm{n}=5)$ \\
\hline \multicolumn{3}{|l|}{ Day 4} \\
\hline $11: 00$ & - & $0.90 \pm 0.56(\mathrm{n}=2)$ \\
\hline Entire period & $34.63 \pm 4.90(\mathrm{n}=23)$ & $1.95 \pm 1.91(\mathrm{n}=31)$ \\
\hline
\end{tabular}

measure nectar concentration at the final time point (Tab. 2), because the refractometer was unable to measure such small amounts of nectar. Pollen viability estimates were high; 94.94 $\pm 2.96 \%$ of the pollen grains were densely stained and had a regular shape. The studied plants presented a mean of $104,071.11 \pm 53,794.42$ pollen grains per flower and 204.27 \pm 18.33 ovules per ovary. The pollen/ovule ratio was 509.48 .

Centris sp., Euglossa sp. and Eulaema nigrita bees were observed performing, respectively, four, two and one legitimate visit to the flowers of Handroanthus serratifolius and were classified as effective pollinators. Exomalopsis fulvofasciata was observed once, behaving as a pollen robber, but can be also considered an occasional pollinator, because it lingered within the floral tube and occasionally touched the stigma when collecting pollen. The stingless bee Trigona spinipes, the carpenter bee Xylocopa sp. and hummingbirds were observed performing, respectively, four, one and five visits to the flowers of $H$. serratifolius. Those three visitors perforated the base of the corolla tube in all visits searching for nectar, which classifies them as nectar robbers. Apis mellifera, T. spinipes, wasps, butterflies and ants were observed collecting nectar from the extrafloral nectaries of the fruits. Those nectaries seemed to be more active during the first stages of fruit development (Fig. 1D-G). It was not possible to use the microcapillaries to collect nectar from those nectaries for measurements of volume and concentration, because the nectar was quite viscous.

\section{Breeding System}

Only hand cross- and self-pollination treatments set fruits, the reproductive efficacy therefore being zero (Tab. 3), although unmarked flowers set fruits naturally in all individuals. The ISI was 0.05 , classifying the species as self-incompatible according to Bawa (1974). Some ovaries from hand self-pollination treatments began to develop
Table 3. Experimental pollinations and fruit-set in Handroanthus serratifolius (Vahl) S. Grose, in the cities of Uberaba and Uberlândia, state of Minas Gerais, Brazil.

\begin{tabular}{lccc}
\hline & Flowers & $\begin{array}{c}\text { Fruit-set at } \\
6-13 \text { days } \\
\text { after the last } \\
\text { pollination } \\
\text { experiment }\end{array}$ & $\begin{array}{c}\text { Fruit-set at } \\
\text { 24-37 days } \\
\text { after the last } \\
\text { pollination } \\
\text { experiment }\end{array}$ \\
\cline { 2 - 4 } & $\mathrm{n}$ & $\begin{array}{c}\mathrm{n}(\%) \text { of } \\
\text { fruits }\end{array}$ & $\begin{array}{c}\mathrm{n}(\%) \text { of } \\
\text { fruits }\end{array}$ \\
\hline Spontaneous self-pollination & 110 & $1(0.9)$ & $0(0.0)$ \\
Hand self-pollination & 110 & $13(11.8)$ & $2(1.8)$ \\
Emasculation & 110 & $0(0.0)$ & $0(0.0)$ \\
Hand cross-pollination & 103 & $63(61.2)$ & $36(34.9)$ \\
Natural pollination (control) & 126 & $8(6.3)$ & $0(0.0)$ \\
Index of self-incompatibility & & & 0.05 \\
Reproductive efficacy & & & 0.00 \\
\hline
\end{tabular}

(Fig. 1E) but were aborted in the first stages. At 6-13 days after the last pollination experiment, when the pistils from spontaneous self-pollination and emasculation were already abscised, $11.8 \%$ of pistils/young fruits from hand self-pollination treatments remained on the studied plants (Tab. 3 ). Because only two fruits from self-pollinations reached maturity $(1.8 \%)$, statistical analyses of fruit length and of the number of seeds per fruit, comparing treatments, were not possible. The fruits developed from hand self-pollinations were much smaller $(14.0 \pm 4.2 \mathrm{~cm}, \mathrm{n}=2)$ than were those developed from hand cross-pollinations $(32.9 \pm 8.2 \mathrm{~cm}, \mathrm{n}$ $=36$ ) and those (unmarked fruits) developed from natural pollinations $(38.1 \pm 7.1 \mathrm{~cm}, \mathrm{n}=8)$, which were collected in order to evaluate fruit length and number of seeds per fruit. The number of seeds per fruit was similar for crosspollinations and natural pollinations $(147.3 \pm 59.6$ and $130.0 \pm 39.2$, respectively). Although the seeds of one fruit from self-pollination were degenerated, the other showed 134 seeds, a number similar to that obtained in the other treatments. However, those 134 seeds were misshapen and none presented an embryo, which allowed us to classify the hexaploid, non-apomictic (monoembryonic) Handroanthus serratifolius as strictly self-sterile.

The analysis of pollen tube growth showed that, at $12 \mathrm{~h}$ after pollination, pollen tubes of both treatments were growing in the style but did not reach the ovary. By $24 \mathrm{~h}$ after pollination, the pollen tubes had reached the ovary and penetrated ovules in both treatments with no difference detected between them. Nor was any difference detected between treatments for ovary length or width at postpollination hour 24 (length: $\mathrm{U}=8.50, \mathrm{p}=0.713$; width: $\mathrm{U}$ $=9.00, \mathrm{p}=0.806$ ), 48 (length: $\mathrm{U}=4.00, \mathrm{p}=0.142$; width: $\mathrm{U}$ $=8.50, \mathrm{p}=0.713$ ), 72 (length: $\mathrm{U}=3.00, \mathrm{p}=1.000$; width: $\mathrm{U}$ $=1.00, \mathrm{p}=0.248$ ) or 120 (length: $\mathrm{U}=5.00, \mathrm{p}=1.000$; width: $\mathrm{U}=2.00, \mathrm{p}=0.245)$. In self-pollinated pistils, an increase in ovary length could be detected between post-pollination 
hours 24 and $120(3.96 \pm 0.30 \mathrm{~cm}$ vs. $10.55 \pm 0.21 \mathrm{~cm} ; \mathrm{H}=$ 9.60; $\mathrm{p}=0.022)$, and some difference in ovary width was also detected among time points $(\mathrm{H}=8.35 ; \mathrm{p}=0.039)$. In cross-pollinated pistils, an increase in ovary length was detected between post-pollination hours 48 and 120 (4.24 $\pm 0.27 \mathrm{~cm}$ vs. $10.16 \pm 0.42 \mathrm{~cm} ; \mathrm{H}=13.43 ; \mathrm{p}=0.004)$, and an increase in ovary width was detected between hours 24 and $120(2.78 \pm 0.44 \mathrm{~cm}$ vs. $4.32 \pm 0.40 \mathrm{~cm} ; \mathrm{H}=10.98 ; \mathrm{p}=0.012)$.

\section{Discussion}

The Handroanthus serratifolius individuals studied were confirmed as monoembryonic and hexaploid, $65 \%$ of the cells in the seedlings of five of the studied plants having $2 n=6 x=120$ chromosomes and $69 \%$ of the cells in the seedlings of one studied plant having $2 \mathrm{n}=6 \mathrm{x}=118$ chromosomes. Reductions of one to six chromosomes were observed in other cells but can be explained by chromosomal overlapping. The five individuals studied for the breeding system were strictly self-sterile, which refutes our hypothesis that neopolyploidy can breakdown the LSI, independent of sporophytic apomixis occurrence. Although the small amount of nectar available could force pollinators to visit a greater number of flowers, self-sterility, combined with high rates of geitonogamy, favored by the large number of flowers displayed, can explain the reduced reproductive efficacy observed in our study, as has been reported for other congeneric species (Barros 2001, Bittencourt \& Semir 2005). In addition, although we observed floral visitors for a period of only $6 \mathrm{~h}$, the low number of visits by effective pollinators could also explain the low reproductive efficacy.

The large floral displays seen in Bignoniaceae species, representative of the "big bang" phenology, often occur in deciduous plants during the dry season, increasing the display area and attracting a wide spectrum of floral visitors from great distances, especially bees (Gentry 1974; Ishii et al. 2008). In Handroanthus serratifolius, anthesis is irregular in terms of the timing of corolla opening and lasts for approximately three days, as in other Handroanthus species (Vitali \& Machado 1995; Barros 2001). However, the flowers are fully receptive only on the first day, as observed for the self-sterile species $H$. ochraceus (Barros 2001). The maintenance of less receptive flowers could also increase the attraction of bees from greater distances (Ishii et al. 2008).

In Handroanthus serratifolius, nectar volume and concentration were similar to those reported for other Handroanthus species and for Jacaranda copaia (Aubl.) D. Don., which show large inflorescences and hundreds of flowers at the peak of flowering (Gottsberger \& SilberbauerGottsberger 2006; Maués et al. 2008). The small amount of accumulated nectar in species with a great amount of flowers can force floral visitors to shorten their visits and to visit a greater number of flowers in order to collect the number of calories needed. Studies involving hummingbirds suggest that plants presenting flowers with little or no nectar may save energy and promote pollinator movement, in mimicry of flowers with uniform secretion rates, but with variable nectar availability due to foraging activity (Feinsinger 1978; Maruyama et al. 2012). In addition, one experimental study showed that when the number of "empty" (nectarless) flowers increases in an inflorescence, the number of visits by bees decreases (Ishii et al. 2008). Given the positive correlation between the percentage of empty flowers and the number of flowers per inflorescence (Takar et al. 2003), larger displays promote proportionally fewer effective visits by bees (Ishii et al. 2008). Therefore, the benefits of large displays in selfincompatible plants may be increased by the presence of empty flowers, encouraging cross-pollinations, although geitonogamy is also favored until pollinators leave one tree to visit another (Maruyama et al. 2012).

The onset of anthesis and flower receptivity during the day, together with the sweet-smelling yellow corolla and $\approx 30 \%$ nectar concentration, observed in Handroanthus serratifolius fit the classical concept of melittophily (Faegri \& van der Pijl 1979). Centridini and Euglossini bees were effective pollinators of $H$. serratifolius, being considered the main pollinators of the family (Bittencourt \& Semir 2004; Correia et al. 2005; Gottsberger \& Silberbauer-Gottsberger 2006; Yanagizawa \& Maiomni-Rodela 2007; Guimarães et al. 2008). The activity of nectar robbers in flowers with small amounts of nectar may mimic that of their activity in empty flowers and promote more movement among inflorescences and trees (Correia et al. 2006; Ishii et al. 2008; Milet-Pinheiro \& Schlindwein 2009). Similar nectar production in young fruits has also been observed for Arrabidaea conjugata (Vell.) Mart. (Correia et al. 2005) and Anemopaegma chamberlaynii Bur. \& K. Schum. (Correia et al. 2006) and seems to be a convergent strategy to avoid seed predation.

Although the pollen/ovule ratio found in the present study corresponds to facultative xenogamy sensu Cruden (1977), Handroanthus serratifolius was classified as strictly xenogamous/self-sterile, indicating that this metric cannot be used as a predictor of the breeding system for this species. According to Cruden (2000), although the pollen/ovule ratio is sufficient to correctly identify the breeding system of many species, xenogamous species with relatively low pollen/ovule ratios should present large pollen grains or stigma areas, which can influence this metric. Especially in the case of $H$. serratifolius, this could be true, because the species is hexaploid and there is a tendency toward larger pollen grains in polyploid populations than in diploid populations (Stebbins 1950; Gould 1957). Further studies are needed in order to confirm this for the species.

The self-pollen tube growth and the ovule penetration observed in self-pollinated pistils, together with the increase in ovary size in self-pollinated pistils that will be aborted, indicate the occurrence of LSI (Gibbs \& Bianchi 1993; Bittencourt et al. 2003; 2011; Bittencourt \& Semir 2005; Gandolphi \& Bittencourt 2010). However, in the Handroanthus serratifolius individuals evaluated here, the fact that two fruits 
from hand self-pollinations with unviable seeds persisted up to the maturation of fruits from hand cross-pollinated pistils can be an indicative of inbreeding depression, which can mimic LSI (Seavey \& Bawa 1986, Bittencourt et al. 2003). In species with LSI, the simultaneous abortion of pistils from self-pollination treatment is expected (Bittencourt et al. 2003). If we consider the self-compatible neopolyploid species of Bignoniaceae as presenting strong inbreeding depression, the similar fruit-set between self- and cross-pollinations in apomictic plants (Bittencourt \& Semir 2005; Bittencourt \& Moraes 2010; Firetti-Leggieri et al. 2013; Sampaio et al. 2013a) would be justified only by the development of adventitious embryos, and we would have to assume that inbreeding depression does not affect endosperm development, which is unlikely. Histological studies of post-pollination events of apomictic self-compatible neopolyploid species of Bignoniaceae do not show endosperm malformations that could be caused by inbreeding depression (Bittencourt \& Moraes 2010; Sampaio et al. 2013a), although a slight delay in endosperm development, which is commonly associated with the action of the LSI, has been reported in Anemopaegma acutifolium (Sampaio et al. 2013a). In addition, inbreeding depression is not expected to occur in neopolyploids such as $\mathrm{H}$. serratifolius, especially allopolyploids, which can avoid inbreeding problems due to high rates of heterozygosity (Barringer 2007, Husband et al. 2008).

We found that Handroanthus serratifolius presented self-sterility in hexaploid, monoembryonic and presumably non-apomictic plants. This result is new to Bignoniaceae, because the neopolyploid species of Anemopaegma and Handroanthus studied to date are clearly self-compatible (Bittencourt \& Semir 2005; Bittencourt \& Moraes 2010; Firetti-Leggieri et al. 2013; Sampaio et al. 2013a). As these neopolyploid and self-compatible species also present polyembryony caused by sporophytic apomixis (Costa et al. 2004; Bittencourt \& Moraes 2010; Sampaio et al. 2013b), it is possible that the self-fertility observed was trigged by the development of adventive embryos, as previously hypothesized (Oliveira et al. 1992; Bittencourt \& Semir 2005; Bittencourt \& Moraes 2010; Sampaio et al. 2013a). Our data suggests that neopolyploidy does not seem to be the main factor causing self-fertility in Handroanthus species.

\section{Acknowledgments}

This work received financial support from the Fundação de Amparo à Pesquisa do Estado de Minas Gerias (FAPEMIG, Foundation for the Support of Research in the State of Minas Gerais; Grant no. APQ 00593-11) and the Brazilian Coordenação de Aperfeiçoamento de Pessoal de Nível Superior/Programa Nacional de Pós-Doutorado (CAPES/PNPD, Office for the Advancement of Higher Education/National Postdoctoral Program; Postdoctoral Fellowship Grant no. 23038008068/2010-95 to DSS). We thank the Companhia Energética de Minas Gerais (CEMIG, Minas Gerais Electric
Company), for providing access to the trucks with cherry pickers and the trained staff that kindly helped us access the treetops, as well as the staff of the Centro Municipal de Estudos e Projetos Educacionais Julieta Diniz (CEMEPE, Julieta Diniz Municipal Center for Educational Projects and Studies), in Uberlândia, and of the Instituto Federal de Educação, Ciência e Tecnologia do Triângulo Mineiro (IFTM, Triângulo Mineiro Federal Institute for Education, Science and Technology), in Uberaba, for the permissions to work with trees located at the study sites. We are also grateful to Lilia Kelly Clemente, Roseli Betoni Bragante, Msc., Tatiane dos Reis Rocha, Thais Arruda Costa Joca and Vinícius Fernandes de Paiva, all of the IFTM, for their help with the field work in Uberaba, as well as to Rafaela Cabral Marinho, for assisting with the chromosome counts, Pietro Kiyoshi Maruyama Mendonça, Msc., of the (São Paulo) State University at Campinas, for the critical reading of the manuscript, and to the anonymous referee, for the valuable suggestions.

\section{References}

Barringer, B.C. 2007. Polyploidy and self-fertilization in flowering plants. American Journal of Botany 94: 1527-1533.

Barros, M.G. 2001. Pollination ecology of Tabebuia aurea (Manso) Benth. \& Hook. and T. ochracea (Cham.) Standl. (Bignoniaceae) in Central Brazil cerrado vegetation. Revista Brasileira de Botânica 24: 255-261.

Bawa, K.S. 1974. Breeding systems of tree species of a low land tropical community. Evolution 28: 85-92.

Bittencourt Júnior, N.S.; Gibbs, P.E. \& Semir, J. 2003. Histological study of post-pollination events in Spathodea campanulata beauv. (Bignoniaceae), a species with late-acting self-incompatibility. Annals of Botany 91: 827-834.

Bittencourt Júnior, N.S. \& Semir, J. 2004. Pollination biology and breeding system of Zeyheria montana (Bignoniaceae). Plant Systematics and Evolution 247: 241-254.

Bittencourt Júnior, N.S. \& Semir, J. 2005. Late-acting self-incompatibility and other breeding systems in Tabebuia (Bignoniaceae). International Journal of Plant Sciences 166: 493-506.

Bittencourt Júnior, N.S. \& Moraes, C.I.G. 2010. Self-fertility and polyembryony in South American yellow trumpet trees (Handroanthus chrysotrichus and H. ochraceus, Bignoniaceae) a histological study of post-pollination events. Plant Systematics and Evolution 288: 59-76.

Bittencourt Júnior, N.S.; Pereira, E.J.; São-Thiago, P.S. \& Semir, J. 2011. The reproductive biology of Cybistax antisyphilitica (Bignoniaceae), a characteristic tree of the South American savannah-like "Cerrado" vegetation. Flora 206: 872-886.

Bullock, S.H. 1985. Breeding systems in the flora of a tropical deciduous forest in Mexico. Biotropica 17: 287-301.

Correia, M.C.R., Pinheiro, M.C.B. \& Lima, H.A. 2005. Biologia floral de Arrabidaea conjugata (Vell.) Mart. (Bignoniaceae). Acta Botanica Brasilica 19: 501-510.

Correia, M.C.R.; Pinheiro, M.C.B. \& Lima, H.A. 2006. Biologia floral e polinização de Anemopaegma chamberlaynii Bur. and K. Schum. (Bignoniaceae). Lundiana 7: 39-46.

Costa, M.E.; Sampaio, D.S.; Paoli, A.A.S. \& Leite, S.C.A.L. 2004. Poliembrionia e aspectos da embriogênese em Tabebuia ochracea (Cham.) Standley (Bignoniaceae). Revista Brasileira de Botânica 27: 395-406.

Cruden, R.W. 1977. Pollen-ovule ratios: a conservative indicator of breeding systems in flowering plants. Evolution 31: 32-46.

Cruden, R.W. 2000. Pollen grains: why so many? Plant Systematics and Evolution 222: 143-165.

Dafni, A.; Kevan, P.G. \& Husband, B.C. 2005. Practical Pollination Biology. Cambridge, Canada. Enviroquest Ltd. 
De Nettancourt, D. 1977. Incompatibility in angiosperms. Sexual Plant Reproduction 10: 185-199.

Dutra, J.C.S. \& Machado, V.L.L. 2001. Entomofauna visitante de Stenolobium stans (Juss.) Seem (Bignoniaceae), durante seu período de floração. Neotropical Entomology 30: 43-53.

Faegri, K. \& Van Der Pjill, L. 1979. The principles of pollination ecology. Pergamon, Press. Oxford.

Feinsinger, P. 1978. Ecological interactions between plants and hummingbirds in a successional tropical community. Ecological Monographs 48: 269-287.

Firetti-Leggiere, F.; Costa, I.R.; Lohman, L.G.; Semir, J. \& Forni-Martins, E.R. 2011. Chromosome studies in Bignonieae (Bignoniaceae): the first record of polyploidy in Anemopaegma. Cytologia 76: 185-191.

Firetti-Leggieri, F.; Lohmann, L.G.; Alcantara, S.; Costa, I.R. \& Semir, J. 2013. Polyploidy and polyembryony in Anemopaegma (Bignonieae, Bignoniaceae). Plant Reproduction 26: 43-53.

Gandolphi, G. \& Bittencourt Júnior, N.S. 2010. Sistema reprodutivo do Ipê-Branco - Tabebuia roseo- alba. (Ridley) Sandwith. Acta Botanica Brasilica 24: 840-851.

Gentry, A.H. 1974. Flowering phenology and diversity in tropical Bignoniaceae. Biotropica 6: 64-68

Gentry, A.H. 1992a. A synopsis of Bignoniaceae ethnobotany and economic botany. Annals of the Missouri Botanical Garden 79: 53-64.

Gentry, A.H. 1992b. Bignoniaceae - Part. II. (Tribe Tecomae). Flora Neotropica Monograph 25 (II): 1-370.

Gibbs, P.E \& Bianchi, M.B. 1993. Post-pollination events in species of Chorisia (Bombacaceae) and Tabebuia (Bignoniaceae) with late -acting self-incompatibility. Botanica Acta 106: 64-71.

Gobatto-Rodrigues, A.A. \& Stort, M.N. 1992. Biologia floral e reprodução de Pyrostegia venusta (Ker-Gawl) Miers (Bignoniaceae). Revista Brasileira de Botânica 15: 37-41.

Goldbatt, P. \& Gentry, A.H. 1979. Cytology of Bignoniaceae. Botanical Notiser 132: 475-482.

Gottsberger, G. \& Silberbauer-Gottsberger, I. 2006. Life in the Cerrado: a south American tropical seasonal ecosystem. Ulm: Reta Verlag, Germany.

Gould, F.W. 1957. Pollen size as related to polyploidy and speciation in the Andropogon saccharoides-A. Barbinodis complex. Brittonia 9: 71-75.

Guerra, M. 1983. O uso do Giemsa em citogenética vegetal - comparação entre a coloração simples e o bandeamento. Ciência e Cultura 35: 190-193.

Guimarães, E.; Stasi, L.C.; Maimoni-Rodella, R.C.S. 2008. Pollination biology of Jacaranda oxyphylla with an emphasis on staminode function. Annals of Botany 102: 669-711.

Husband, B.C., Ozimec, B., Martin, S.L. \& Pollock, L. 2008. Mating consequences of polyploid evolution in flowering plants: current trends and insights from syntetic polyploids. International Journal of Plant Sciences 169: 195-206.

Ishii, H.S.; Hirabayashi, Y. \& Gaku, K. 2008. Combined effects of inflorescence architecture, display size, plant density and empty flowers on bumble bee behaviour: experimental study with artificial inflorescences. Oecologia 156: 341-350.

Kearns, C.A. \& Inouye, D.W. 1993. Techniques for pollination biologists. Niwot, University Press of Colorado.

Levin, D.A. 2002. The role of chromosomal change in plant evolution. Oxford, Oxford University Press.

Lorenzi, H. 1992. Árvores brasileiras: manual de identificação e cultivo de plantas arbóreas nativas do Brasil. Nova Odessa, Instituto Plantarum de Estudos da Flora Ltda.

Martin, F.W. 1959. Staining and observing pollen tubes in the style by means of fluorescence. Stain Technology 34: 125-128.

Maruyama P.K.; Custódio, L.N. \& Oliveira, P.E. 2012. When hummingbirds are the thieves: visitation effect on the reproduction of Neotropical snowbell Styrax ferrugineus Nees \& Mart (Styracaceae). Acta Botanica Brasilica 26: 58-64.

Maués, M.M.; Oliveira, P.E.A.M. \& Kanashiro, M. 2008. Pollination biology in Jacaranda copaia (Aubl.) D. Don. (Bignoniaceae) at the "Floresta Nacional do Tapajós", Central Amazon, Brazil. Revista Brasileira de Botânica 31: 517-527.
Mc Dowel, E.M. \& Trump, B. 1976. Histological fixatives for diagnostic light and electron microscopy. Archives of Pathology \& Laboratory Medicine 100: 517-527.

Mendes-Rodrigues, C.; Sampaio, D.S.; Costa, M.E.; Caetano, A.P.S.; Ranal, M.A.; Bittencourt Júnior, N.S. \& Oliveira, P.E. 2012. Polyembryony increases embryo and seedling mortality but also enhances seed individual survival in Handroanthus species (Bignoniaceae). Flora 207: 264-274.

Milet-Pinheiro, P. \& Schlindwein, C. 2009. Pollination in Jacaranda rugosa (Bignoniaceae): Euglossine pollinators, nectar robbers and low fruit set. Plant Biology 11: 131-141.

Oliveira, P.E.; Gibbs, P.E.; Barbosa, A.A. \& Salvador, T. 1992. Contrasting breeding systems in two Eriotheca (Bombacaceae) species of the Brazilian cerrados. Plant Systematics and Evolution 197: 207-219.

Oliveira, M.F.; Lemos, T.L.G.; Mattos, M.C.; Segundo, T.A.; Santiago, G.M.P. \& Braz-Filho, R. 2002. New enamine derivatives of lapachol and biological activity. Anais da Academia Brasileira de Ciências 74: $211-221$

Olmstead, R.G.; Zjhra, M.L.; Lohman, L.G.; Grose, S.O. \& Eckert, A.J. 2009. A molecular phylogeny and classification of Bignoniaceae. American Journal of Botany 96: 1731-1743.

Pannell, J.R.; Obbard, D.J. \& Buggs, R.J.A. 2004. Polypolidy and the sexual system: what can we learn from Mercurialis annua? Biological Journal of the Linnean Society 82: 547-560.

Piazzano, M. 1998. Números cromosómicos en Bignoniaceae de Argentina. Kurtziana 26: 179-189.

Richards, A.J. 1986. Plant Breeding Systems. London, George Allen \& Unwin.

Qu, R.; Li, X.; Luo, Y.; Dong, M.; Xu, H.; Chen, X. \& Dafini, A. 2007. Winddragged corolla enhances self-pollination: a new mechanism of delayed self-pollination. Annals of Botany 100: 1155-1164.

Ramsey, J. \& Schemske, D.W. 1998. Pathways, mechanisms, and rates of polyploid formation in flowering plants. Annual Review of Ecology and Systematics 29: 467-501.

Ruiz, T. \& Arroyo M.T.K. 1978. Plant reproductive ecology of a secondary deciduous forest in Venezuela. Biotropica 10: 22 1-230.

Salustiano, E.S.J.; Netto, C.D.; Fernandes, R.F.; Silva, A.J.M.; Bacelar, T.S.; Castro, C.P.; Buarque, C.D.; Maia, R.C.; Rumjamanek, V.M. \& Costs, P.R.R. 2010. Comparison of the cytotoxic effect of lapachol, alphalapachone and pentacyclic 1,4-naphthoquinones on human leukemic cells. Investigational New Drugs 28: 139-44.

Sampaio, D.S. 2010. Biologia reprodutiva de espécies de Bignoniaceae ocorrentes no Cerrado e variações nos sistema de autoincompatibilidade. PhD Dissertation, Instituto de Biologia, Universidade Federal de Uberlândia, MG, Brazil.

Sampaio, D.S.; Bittencourt Júnior, N.S. \& Oliveira P.E. 2013a. Mating in the pseudogamic apomictic Anemopaegma acutifolium DC: another case of pseudo-self-compatibility in Bignoniaceae? Plant Biology doi:10.1111/j.1438-8677.2012.00692.x

Sampaio, D.S.; Bittencourt Júnior, N.S. \& Oliveira P.E. 2013b. Sporophytic apomixis in polyploid Anemopaegma species (Bignoniaceae) from Central Brazil. Botanical Journal of the Linnean Society 173: 77-91.

Seavey, S.R. \& Bawa, K.S. 1986. Late-acting self-incompatibility in angiosperms. The Botanical Review 52: 195-219.

StatSoft. 2004. Statistica for Windows, Release 7.0. Tulsa, OK: StatSoft Inc.

Stebbins, G.L. 1950. Variation and evolution in plants. New York, Columbia University Press.

Takar, J.D.; Kunte, K.; Chauhan, A.K.; Watve, A.V. \& Watve, M.G. 2003. Nectarless flowers: ecological correlates and evolutionary stability. Oecologia 136: 565-570.

Vitali, M.I. \& Machado, V.L.L. 1995. Entomofauna visitante das flores de Tabebuia chrysotricha (Mart.) Standl. (Bignoniaceae). Anais da Sociedade de Entomologia do Brasil 24: 77-88.

Yanagizawa, Y.A.N. \& Maimoni-Rodella, R.C.S. 2007. Floral visitors and reproductive strategies in five melittophilous species of Bignoniaceae in southeastern Brazil. Brazilian Archives of Biology and Technology 50: 1043-1050. 